\title{
PHARMACOGNOSTIC STANDARDISATION OF CAYRATIA PEDATA (LAM.) GAGNEP. VAR. GLABRA GAMBLE-AN ENDEMIC AND ENDANGERED MEDICINAL CLIMBER IN THIASHOLA, NILGIRIS
}

\author{
SHARMILA S. ${ }^{*}$, KALAICHELVI K., DHIVYA S. M. \\ ${ }_{1}^{1}$ PG and Research Department of Botany, Vellalar College for Women (Autonomous), Thindal, Erode 638012, Tamil Nadu, India \\ Email: drsharmilas@yahoo.com
}

Received: 29 Jan 2017 Revised and Accepted: 02 Nov 2017

\begin{abstract}
Objective: The main objective was to develop a detailed pharmacognostic profile of aerial plant parts of Cayratia pedata (Lam.) Gagnep. var. glabra Gamble (Vitaceae) an endemic and endangered medicinal taxon distributed in Thiashola, Manjoor, Nilgiris South Division, Western Ghats.

Methods: All pharmacognostic and phytochemical evaluation of Cayratia pedata var. glabra was carried out by different evaluation methods like macroscopic, microscopic, physicochemical, minerals, vitamins, heavy metal analysis, phytochemical studies and GC/MS analysis.

Results: The macroscopical investigation revealed that the stem is hirsute and grows up to a height of $12 \mathrm{~m}$. The leaves are alternate, oblong and acuminate with smooth surface and texture $(3$ to $6 \mathrm{~cm}$ ). Tendril, leaf-opposed, branched, wiry and coiled. Flowers yellow and fruits bilobed. The anatomical study in tendril and old stem provides a set of characters specific for C. pedata var. glabra with which one can establish the identity of the plant in fragmentary form. The availability of macro and micro elements were studied in plant powder (ash). The macro elements, calcium $(34.50 \mathrm{mg} / 100 \mathrm{~g})$ and potassium $(11.45 \mathrm{mg} / 100 \mathrm{~g})$ were present in high amount likewise in microelements manganese $(4.56 \mathrm{mg} / 100 \mathrm{~g})$ was significantly higher. The fat-soluble vitamin A-retinol (156.8 iu) was present in higher amount when compared to other vitamins. Results of the heavy metal analysis revealed that the concentration of Lead was less than $1 \mathrm{ppm}$ and chromium occurred in traces. The other heavy metals like mercury, cadmium and arsenic were totally absent. The percent yield was maximum in methanol extract (11\%) followed by water extract (10\%). The preliminary phytochemical screening revealed the presence of alkaloids, flavonoids, glycosides, phenols and tannins, steroids and sterols, triterpenoids and volatile oil. GC-MS analysis showed the presence of 15 compounds such as Heptadecane (17.36\%), Silane, trichlorooctadecyl (17.29\%), Eicosane (15.44\%), Heptane, 2,2,3,3,5,6,6-heptamethyl (14.71\%), n-Tetradecyltrichlorosilane (13.64\%), Pentadecane (10.55\%), Iron, tricarbonyl [N-(phenyl-2-pyridinylmethylene) benzenamine- $\left.\mathrm{N}, \mathrm{N}^{\prime}\right](10.91 \%)$ and Octadecane $(8.93 \%)$ were the other major compounds present.
\end{abstract}

Conclusion: The above parameters, which are being testimony for the first time, are momentous towards establishing the pharmacognostic profile for future identification and authentication of genuine plant material. This approach is important for this time since this species is listed in Red data book as per the IUCN red list categories and criteria due to their lower germination percentage and also due to its enriched medicinal value.

Keywords: Cayratia pedata var. glabra, Thiashola, Pharmacognosy, Physicochemical

(C) 2017 The Authors. Published by Innovare Academic Sciences Pvt Ltd. This is an open-access article under the CC BY license (http://creativecommons.org/licenses/by/4.0/] DOI: http://dx.doi.org/10.22159/ijpps.2017v9i12.17352

\section{INTRODUCTION}

In modern days a renewed interest is developed in drugs of natural origin simply because they are considered as green medication and this is always supposed to be safe. Another feature which emphasizes this attention is the incidences of harmful nature of synthetic drugs which are regarded as harmful to human beings and environment. The advantage of natural drugs is their easy availability, economic and less or no side effects but the disadvantage is that they are the victims of adulteration. Standardization of herbal medicines and quality control of the plant raw materials are very important aspects of manufacture and supply of herbal drugs. The importance of herbals is realized and efforts are being made to satisfy the regulatory requirements.

India is perhaps one of the largest producers of medicinal herb and is rightly called the "Botanical garden of the world". It is one of the leading countries enjoying a major global market share in medicinal plants. Herein, Tamilnadu is rich in medicinal plants, especially in the hilly tract of the Western Ghats, which is the storehouse of numerous high-value medicinal plants. The tribal community used 1,214 plant species to cure 121 diseases. To this date, as per the IUCN red list categories and criteria, there are about 200 plant species are red-listed, of which most of the medicinal plants are hitherto used by common people.

The documentation of ethnopharmacobotanical information of herbaceous plants was carried out in Thiashola, Manjoor, Nilgiris
South Division, Western Ghats with proper permission obtained from the Principal Chief Conservator of Forests, Chennai and the District Forest Officer, Ooty under Section 28 (i) of Wildlife Protection Act, 1972, during 2009 and 2010. With the assistance of experienced and elderly tribes, traditional knowledge of this region informal interviews were conceded and documented. From the conducted survey 106 species were enumerated of this 76 have been recognized as medicinally and economically important species. Among the foresaid species, an endangered fragile species, Cayratia pedata (Lam.) Gagnep. var. glabra Gamble has been selected for further study since this species is listed in Red data book as per the IUCN red list categories and criteria due to their lower germination percentage and also due to its enriched medicinal value. The aerial plant parts of this species are used by the rural folk similar to other Cayratia species in curing skin diseases, hemorrhage, refrigerant, hysteria, wound healing and ulcers but it is unexplored commercially. A perusal of the previous literature revealed that this medicinal plant is unexplored, so a detailed systematic pharmacognostic study was carried out [1-3].

\section{MATERIALS AND METHODS}

Chemicals and instruments

All the chemicals used for the study were of laboratory grade. Compound microscope, watch glass, glass slides, cover slips and other common glasswares were used in this experiment. Photographs were taken with using Nikon Labphot 2 Microscopic 
Unit and Trinocular microscope. Acetone and methanol solvents and reagents used for staining different sections like Toluidine blue, Safranin and IKI-Lugol's iodine were procured from The Precision Scientific Co., Coimbatore, India.

\section{Collection and authentication of study plant material}

Aerial plant of Cayratia pedata var. glabra (fig. 1) were collected from Thiashola, Manjoor, Nilgiris South Division, Western Ghats and the voucher herbarium specimen was processed followed by standard methods Jain and Rao [4]. The collected plants were identified with the help of the existing Floras [5-7] and compared with type specimens available in the herbarium of Botanical Survey of India, Southern Circle, TNAU Campus, Coimbatore (No. BSI/SRC/5/23/2010-11/Tech. 1300), Tamil Nadu and the type specimens were deposited for further reference.

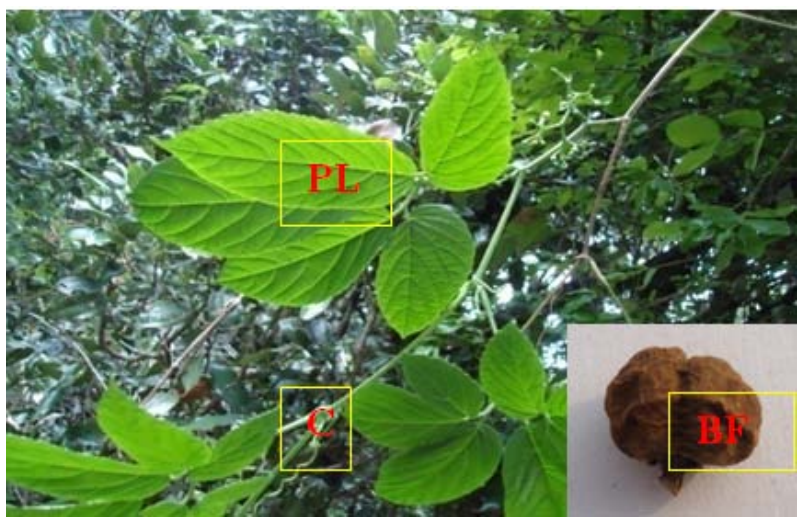

Fig. 1: Flowering twig of Cayratia pedata var. glabra, PL: Pedate Leaf; C: Climber; BF: bilobed fruit

\section{Macroscopic and histological studies}

The macroscopy and microscopic studies of this plant were carried out according to the method of [8-9]. Fresh and healthy stem and tendrils were separated from the plant and thoroughly washed with running water to remove the adherent impurities for anatomical studies. Some quantities of leaves and total aerial parts were air dried, powdered and stored in airtight containers for further studies. Fresh tendrils and stem were used for freehand section cutting and were fixed in FAA and dehydrated with TBA as per the schedule is given by Sass [10]. The paraffin-embedded specimens were sectioned with the help of Rotary Microtome. Dewaxing of the sections was done by customary procedure Johansen [8]. The sections were stained with Toluidine blue, Safranin and IKI-Lugol's iodine as per the method of O'Brien [11]. After clearing the T. S various microscopical studies were carried out in the study plant. Photographs of different magnifications were taken with NIKON ALPHA PHOTO-2 microscopic unit. Brightfield was used for normal observations whereas polarized light was employed for the detailed study of crystals and starch grains. Descriptive terms of the anatomical features are taken from the standard anatomy book [12].

\section{Physico-chemical and extractive (\%) analysis}

The parameters like quantification of minerals, vitamins and heavy metals were studied according to the official method [13-15] and the WHO guidelines on quality control methods for medicinal plants material [16]. The air-dried, powdered plant material was extracted in Soxhlet apparatus successively with different solvents in the increasing order of polarity [Acetone $\left(56.5^{\circ} \mathrm{C}\right)$, Methanol $\left(64.7^{\circ} \mathrm{C}\right)$ and Water $\left.\left(99.98^{\circ} \mathrm{C}\right)\right]$. The extracts were evaporated using a rotary evaporator and water extract with a freeze dryer. The residues were weighed and it is used for the prediction of yield percentage (\%).

\section{Preliminary phytochemical screening}

Phytochemical screening of different successive solvent extracts was carried out using the standard procedure described by Kokate et al. [17].

\section{GC/MS analysis}

\section{Extraction of essential oil}

The essential oil was extracted by hydrodistillation method. The fresh leaves of C. pedata var. glabra were collected $(500 \mathrm{~g})$ and placed in round bottom flask of the Clevenger type apparatus with water. The oil was hydrodistilled 3-4 $\mathrm{h}$ in this apparatus. The resulting oil was collected, preserved in a sealed sample tube and stored under refrigeration until analysis.

\section{GC MS conditions}

The essential oil was subjected to GC-MS analysis on the instrumentTHERMO MS DSQ II-TR, 5-MS capillary standard non-polar column and the GC-MS trace ultra-version 5.0 software employing the following conditions: RT x 5 MS column $(30 \times 0.25$ mmIDx1 $1 \mu \mathrm{M} d f$, composed of $100 \%$ Dimethyl poly diloxane). Initially, oven temperature was maintained at $70{ }^{\circ} \mathrm{C}$ for $2 \mathrm{~min}$, and the temperature was gradually increased up to $250^{\circ} \mathrm{C}$ at 10 and $1 \mu \mathrm{L}$ of the sample was injected for analysis. Helium gas $99.995 \%$ of purity was used as a carrier gas as well as an eluent. The flow rate of helium gas was set to $1 \mathrm{ml} / \mathrm{min}$. The sample injector temperature was maintained at $250{ }^{\circ} \mathrm{C}$ and the split ratio is 10 throughout the experiment periods. The ionization mass spectroscopic analysis was done with $70 \mathrm{eV}$. The mass spectrum was recorded for the mass range $40-1000 \mathrm{~m} / \mathrm{z}$ for about 35 min. Identification of components was based on a comparison of their mass spectra. The identification of compounds was based on the comparisons of their mass spectra with NIST Library 2008 WILEY8, FAME. Total GC running time is $48.51 \mathrm{~min}$ [18].

\section{RESULTS AND DISCUSSION}

To ensure the quality of herbal products, proper control of starting material is utmost essential. Various techniques are used for the standardization of medicinal plants of therapeutic potential. But identification and evaluation of plant drugs by pharmacognostical studies is still more reliable, accurate and inexpensive.

\section{Macroscopic characteristics}

C. pedata var. glabra is a large, fragile liana. The leaves are alternate, pedately 5 foliolate $(8-15 \mathrm{~cm})$ long and grows up to a height of $(8-12$ $\mathrm{m})$ with nodes and internodes. Leaflets are elliptic, oblong, serrate (712 leaflets; 3-6 cm long) and an acuminate apex. Leaves are dark green in colour with characteristic odour and bitter taste. Fruits are slightly green in colour, the fleshy and bilobed shape at its apex. Fruit shape is the important differentiable characterization among the other genus. Several earlier workers have adopted macroscopical features as one of the effective parameters for the pharmacognostical identification of several plant-derived crude drugs.

\section{Anatomical description of tendril}

The tendril superficially resembles a young stem. In transactional view, it is circular ( $1.75 \mathrm{~mm}$ thick) with a wavy outline (fig. $2 \mathrm{~A}$ and 2B). It consists of a thin continuous epidermal layer of small semicircular cells with prominent cuticle. The cortex consists of outer wide patches of collenchyma alternating with the narrow bridge of parenchymatous cells in the furrows (fig. 2B). The inner cortex consists of two or three layers of parenchyma cells and prominent, discrete circular masses of fibres. The fibres are thickly walled and lignified. The vascular cylinder is thin $(150 \mu \mathrm{m}$ thick), wide and hollow enclosing wide parenchymatous pith. It comprises most thick walled lignified radial, parallel files of fibres; vessels restricted to a few elements situated along the inner border of the xylem cylinder (fig. 2B). Phloem occurs in a thin layer on the outer periphery of the xylem cylinder. Botanical identification of a phytodrug involves two steps. One is the identification of the plant by its floral characters and the other is a diagnosis of the plant with its microscopic characters. The latter procedure is useful for identification of fragmentary plant specimens. Certain microscopical characters are vulnerable for changes due to environmental stress. Yet, there are many anatomical features that are least modified by external factors and such features are specific at the species level or genus and family level. Early plant morphologist Robert Hook [19] clearly demonstrated that each kind of plant has its own distinctive structure by means of which it can be recognized. 


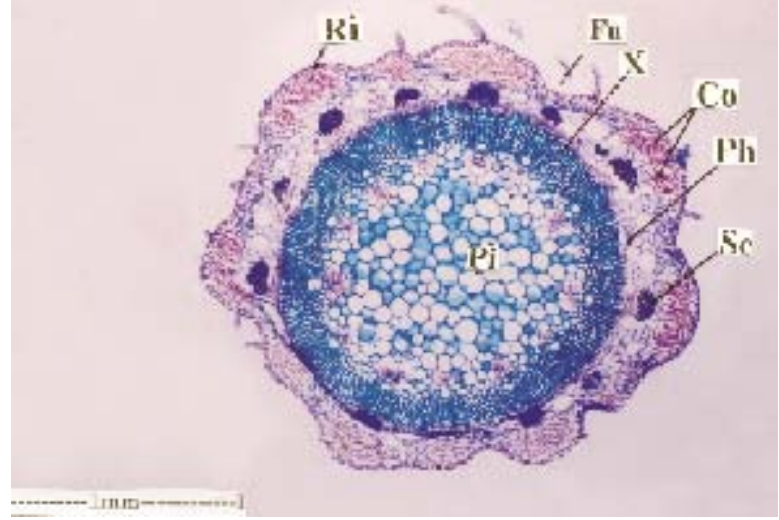

Fig. 2A: T. S of Ground plan view of Tendril

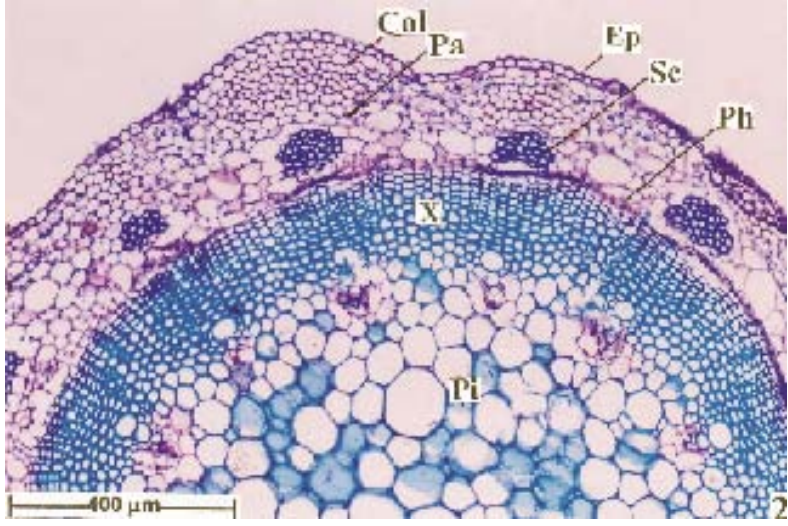

Fig. 2B: T. S of sector enlarged view of Tendril

Co: Cortex; Col: Collenchyma; Ep: Epidermis; Fu: Furrow; Pa: Parenchyma; Ph: Phloem

Pi: Pith; Ri: Ridge; Sc: Sclerenchyma; X: Xylem

\section{Anatomical description of old stem}

The old stem is circular in outline ( $3.5 \mathrm{~mm}$ thick) with an even surface, ridges and furrows have disappeared due to growth in thickness. It has undergone considerable quantum of secondary growth. The epidermis is intact and has not broken at any part of the stem. The cortex has outer, stretch masses of fibres and narrow parenchyma tissue lying in between the sclerenchyma masses. Semicircular discrete masses of fibres are located in a regular circle around the vascular cylinder. The fibres have thick lignified walls (fig. 3A and 3B). This is in corroboration with the work of [20]. The

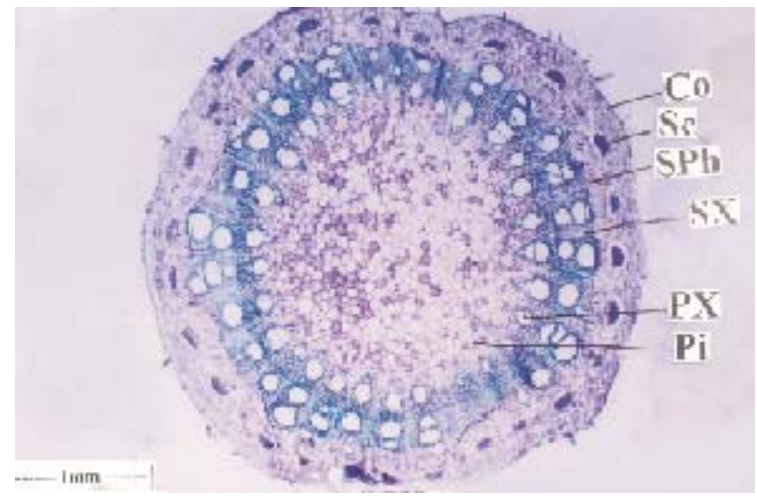

Fig. 3A: T. S of Ground plan view of old stem vascular cylinder consists of fairly wide phloem tissue which occurs all around the xylem cylinder. It is interrupted by slightly dilated phloem rays (fig. 3C). Xylem cylinder is thick and continuous short rows of primary xylem occur along the inner border of the xylem cylinder. The secondary xylem includes wide, circular, thin-walled, mostly solitary vessels and ground tissue of thin-walled, lignified fibres. The fibres occur in regular radial files (fig. 3C).

The diameter of the vessels ranges from 80 to $200 \mu \mathrm{m}$. Wheeler and LaPasha and Pragasam [21, 22] observed that anatomy of Cissus sp. supports the close relationship with C. pedata var. glabra.

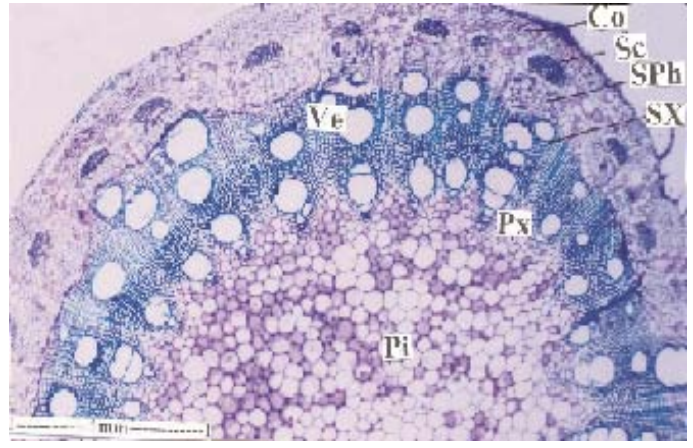

Fig. 3B: T. S of sector enlarged view of old stem

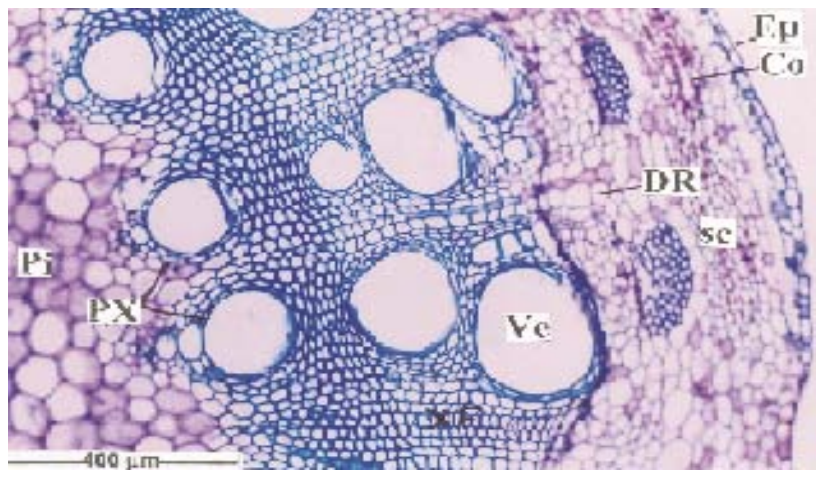

Fig. 3C: T. S of sector further enlarged view of old stem

Co: Cortex; Ep: Epidermis; DR: Dilated Ray; Pi: Pith; PX: Primary Xylem; Sc: Sclerenchyma

Ve: Vessel; XF: Xylem Fibres` 


\section{Physico-chemical analysis}

\section{Estimation of minerals}

The availability of macro and micro elements were studied in plant powder (ash) of C. pedata var. glabra and the observed results are presented in table 1 . The concentration of macro and micro elements was as follows. Calcium( $34.50 \mathrm{mg} / 100 \mathrm{~g})$, magnesium $(1.24 \mathrm{mg} / 100 \mathrm{~g})$, sodium $(0.56 \mathrm{mg} / 100 \mathrm{~g})$, potassium $(11.45$ $\mathrm{mg} / 100 \mathrm{~g})$, manganese $(4.56 \mathrm{mg} / 100 \mathrm{~g})$, zinc $(0.11 \mathrm{mg} / 100 \mathrm{~g})$, iron $(2.67 \mathrm{mg} / 100 \mathrm{~g})$ and copper $(0.98 \mathrm{mg} / 100 \mathrm{~g})$. Among the various macro elements, calcium and potassium were present in high amount. The microelement manganese $(4.56 \mathrm{mg} / 100 \mathrm{~g})$ was significantly higher in C. pedata var. glabra than the others. Likewise, the elements such as $\mathrm{K}, \mathrm{Ca}, \mathrm{Zn}, \mathrm{Na}, \mathrm{Fe}, \mathrm{Pb}, \mathrm{Cd}, \mathrm{Cu}, \mathrm{Mg}, \mathrm{Cr}$ and $\mathrm{Co}$ in root powder of $C$. quadrangularis were analysed by [23].

Calcium is necessary for neuromuscular mechanism [24], dietary supplements of $\mathrm{Mg}$ have been reported to be effective in treating depression [25], sodium maintains the osmotic pressure, irritability of muscle, permeability of the cell and heartbeat, glucose absorption [25], potassium deficiency leads to stroke, diabetes and hypertension [26], Mn deficiency, results in young ones with ataxia, bone deformities and liver arginase activity in animals [25], Zn deficiency includes hepatic porphyria and proteinuria, wound healing, lesions of skin, dwarfism and hypogonadism [27], deficiency of iron results in hypochromic nutritional anemia and ulcerative lesion in the gastrointestinal tract [25] and deficiency of $\mathrm{Cu}$ may produce hepatolenticular degeneration of Wilson's disease [24]

Table 1: Mineral values of $C$. pedata var. glabra powder

\begin{tabular}{ll}
\hline Minerals & $\begin{array}{l}\text { Values }(\mathbf{m g} / \mathbf{1 0 0} \text { g) dry } \\
\text { weight }{ }^{\#}\end{array}$ \\
\hline Macroelements & $34.5 \pm 1.74$ \\
Calcium & $01.24 \pm 0.08$ \\
Magnesium & $00.56 \pm 0.00$ \\
Sodium & $11.45 \pm 8.14$ \\
Potassium & \\
Microelements & $04.56 \pm 1.54$ \\
Manganese & $00.11 \pm 0.07$ \\
Zinc & $02.67 \pm 0.57$ \\
Iron & $00.98 \pm 0.43$ \\
Copper & \\
\hline
\end{tabular}

\#Values are means of three independent analysis $\pm \mathrm{S}$ tandard Deviation

\section{Estimation of vitamins}

Vitamins are organic compounds required for growth and maintenance of life, functioning as regulatory substances by performing specific functions and are essential. The fat soluble and water soluble vitamins were found in C. pedata var. glabra plant powder. The results are presented in table 2 . The fat-soluble vitamin A-retinol (156.8 iu) was higher than water-soluble vitamin $\mathrm{B}_{2}$ riboflavin ( $1.14 \mathrm{iu}$ ) followed by vitamin $\mathrm{B}_{3}$-niacin $(0.67 \mathrm{iu})$, vitamin $\mathrm{B}_{1}$-thiamine $(0.56 \mathrm{iu})$, niacinamide- $(0.56 \mathrm{iu})$ and vitamin $\mathrm{B}_{12}-$ cyanocobalamin (0.0013 iu) respectively. Vitamin E (tocopherol), vitamin $B_{5}$ (pantothenic acid) and vitamin $B_{9}$ - (folic acid) were occurred in traces.

Vitamin $\mathrm{A}$ and $\beta$-carotene are unique radio-protective agents (Levenson et al., 1984). Vitamin A helps to maintain good sight and prevents eye diseases. Both the vitamins have antioxidant property [28]. Vitamin $B_{12}$ is the largest and the most complex of all the vitamins. Cobalamin is the term used to refer to a group of cobaltcontaining vitamins [29].

Table 2: Estimation of vitamins in the plant powder of $C$. pedata var. glabra

\begin{tabular}{ll}
\hline Vitamins & Values (iu) ${ }^{\#}$ \\
\hline Vitamin A & $156.8 \pm 49.4$ \\
Vitamin E & In traces \\
${\text { Vitamin } B_{1}}_{\text {Vitamin } B_{2}}$ & $0.56 \pm 0.46$ \\
Vitamin $B_{3}$ & $1.14 \pm 0.09$ \\
Vitamin $B_{5}$ & $0.67 \pm 0.57$ \\
Vitamin $B_{12}$ & In traces \\
Niacinamide & $0.13 \pm 0.01$ \\
Folic acid & $0.56 \pm 0.61$ \\
\hline
\end{tabular}

\# Values are means of three independent analysis \pm Standard Deviation

\section{Estimation of heavy metals}

Table 3 showed the concentration of heavy metals found in plant powder of C. pedata var. glabra. The concentration of Lead was less than $1 \mathrm{ppm}$ and chromium occurred in traces. The other heavy metals like mercury, cadmium and arsenic were totally absent. Chromium deficiency leads to arteriosclerotic heart diseases [30], accelerating insulin utilization of glucose, maintains the normal cholesterol level in blood, incorporation of amino acids in heart muscle [25]. The less than $1 \mathrm{ppm}$ of lead, nil amount of mercury, cadmium and arsenic and traces of chromium in the sample analysed indicating the water pollution free edaphic condition of Thiashola forest.

Table 3: Estimation of heavy metals in the plant powder of $C$. pedata var. glabra

\begin{tabular}{ll}
\hline Heavy metals & Values (ppm) \\
\hline Lead & $<1$ \\
Mercury & Nil \\
Cadmium & Nil \\
Arsenic & Nil \\
Chromium & In traces \\
\hline
\end{tabular}

\section{Prediction of yield percentage}

The air-dried, the powdered sample was extracted with different solvents for the phytochemical and pharmacological studies. The yield of different solvent extracts during successive solvent extraction was calculated and presented in table 4 . The percent yield was maximum in methanol extract $(11 \%)$ followed by water extract (10\%). The acetone extract shows minimum yield (7.5\%). The above findings indicated the concentration of secondary metabolites [20].

\section{Qualitative phytochemical screening}

The preliminary phytochemical screening revealed the presence of alkaloids, flavonoids, glycosides, phenols and tannins, steroids and sterols, triterpenoids and volatile oil. The chloroform extract was more efficient than ethanol (table 5). All extracts showed the negative response to saponins. The preliminary data collected in the present study helped in the preparation of an authentic preliminary phytochemical profile.

Table 4: Extractive values of $C$. pedata var. glabra powder in various solvents

\begin{tabular}{lll}
\hline Method of extraction & Solvents used & Yield (\%) $^{\#}$ \\
\hline Continuous hot percolation & Acetone & $7.50 \pm 1.21$ \\
using Soxhlet apparatus & Methanol & $11.0 \pm 2.00$ \\
Hot and cold maceration & Water & $10.0 \pm 2.00$ \\
\hline
\end{tabular}

\# Values are means of three independent analysis $₫$ Standard Deviation 
Screening of plant powder extracts

\begin{tabular}{llll}
\hline Chemical constituents & Chemical tests & Chloroform extract & Ethanol extract \\
\hline Alkaloids & Dragendorff's reagent & - & + \\
& Mayer's reagent & + & - \\
& Wagner's reagent & - & - \\
Anthroquinones & Borntrager's test & + & + \\
Flavonoids & Alkaline reagent test & + & + \\
Glycosides & Zinc hydrochloride test & + \\
Phenols and tannins & Borntrager's test & - & + \\
Saponins & Ferric chloride test & + \\
Steroids and sterols & Foam test & $\mathbf{+}$ \\
Triterpenoids & Salkowski test & $\mathbf{+}$ \\
Volatile oil & Sulfur test & - \\
\end{tabular}

Note: '+',-' indicates the presence/absence of compounds

\section{Gas chromatography/Mass spectrometry (GC/MS) analysis}

The components present in the essential oil of $C$. pedata var. glabra leaves were identified by the GC-MS analysis. The GC-MS Chromatogram of the number of peaks of the compounds detected was shown in fig. 4. This analysis reveals the presence of phytoconstituents belonging to the type-acids, esters, alcohols, ethers, hydrocarbons, alkane, fatty acids etc. The identified compounds of the essential oil their retention indices, percentage composition, chemical structure and activities are given in table 6 and 7. Fifteen compounds were detected from the essential oil of $C$. pedata var. glabra. The results showed the presence of Heptadecane
(17.36\%), Silane, trichlorooctadecyl (17.29\%), Eicosane (15.44\%), Heptane, 2,2,3,3,5,6,6-heptamethyl (14.71\%), n-Tetradecyltrichlorosilane $(13.64 \%)$, Pentadecane $(10.55 \%)$, Iron, tricarbonyl [N(phenyl-2-pyridinylmethylene) benzenamine-N, N'] (10.91\%) and Octadecane $(8.93 \%)$ were the other major compounds present (table 6). Table 7 lists the major phytocomponents and their chemical structure and biological activities obtained through the GC-MS studies. The predominant compounds have the property of antioxidant, antifungal, antibacterial, antiallergic, chemopreventive and anti-cancer activity. The biological activities listed are based on Dr. Duke's phytochemical and ethnobotanical databases by Dr. Jim Duke of the Agricultural Research Service/USDA.

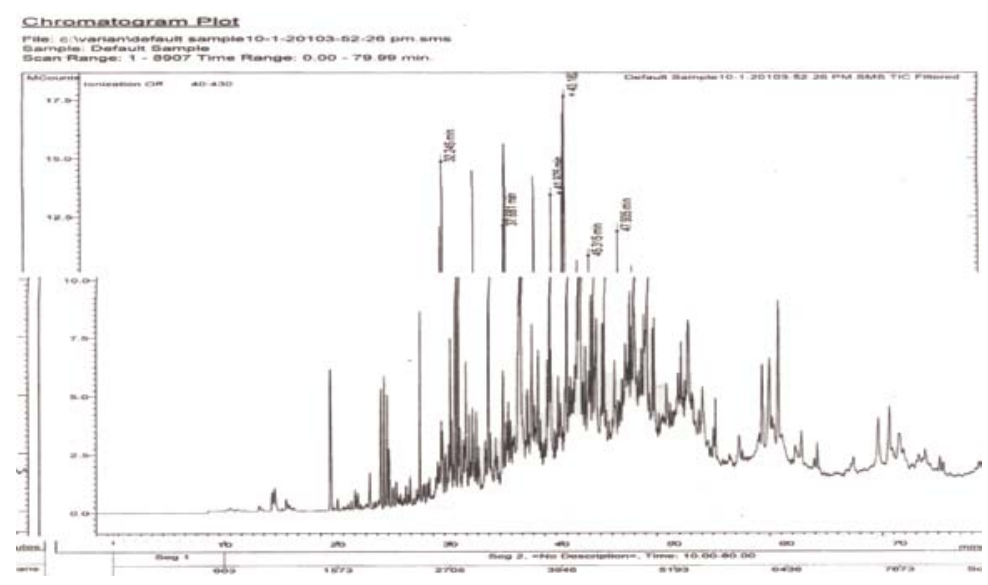

Fig. 4: Chromatogram profile of essential oil of $C$. pedata var. glabra

Table 6: GC/MS analysis of essential oil of $C$. pedata var. glabra

\begin{tabular}{|c|c|c|c|c|}
\hline RT (Min) & Chemical compounds & $\begin{array}{l}\text { Molecular } \\
\text { formula }\end{array}$ & $\begin{array}{l}\text { Molecular } \\
\text { weight }\end{array}$ & $\begin{array}{l}\text { Peak area } \\
(\%)\end{array}$ \\
\hline 18.14 & 1,2-Benzenedicarboxylic acid, diisooctyl ester & $\mathrm{C}_{24} \mathrm{H}_{38} \mathrm{O}_{4}$ & 390 & 1.26 \\
\hline 21.47 & Neophytadiene & $\mathrm{C}_{20} \mathrm{H}_{38}$ & 278 & 3.67 \\
\hline 26.71 & Dibutyl phthalate & $\mathrm{C}_{16} \mathrm{H}_{22} \mathrm{O}_{4}$ & 278 & 6.27 \\
\hline 32.24 & Silane, trichlorooctadecyl & $\mathrm{C}_{18} \mathrm{H}_{37} \mathrm{Cl}_{3} \mathrm{Si}$ & 386 & 17.29 \\
\hline 33.17 & Cyclohexasiloxane, dodecamethyl & $\mathrm{C}_{12} \mathrm{H}_{36} \mathrm{O}_{6} \mathrm{Si}_{6}$ & 444 & 1.89 \\
\hline 35.63 & $\begin{array}{l}\text { 5-Benzyloxymethyl-2,2-dimethyl-1,3-dioxolan-4-yl ester of (4R,5R)-p- } \\
\text { Toluenesulfonic acid }\end{array}$ & $\mathrm{C}_{21} \mathrm{H}_{26} \mathrm{O}_{6} \mathrm{~S}$ & 406 & 1.90 \\
\hline 36.12 & n-Tetradecyltrichlorosilane & $\mathrm{C}_{14} \mathrm{H}_{29} \mathrm{Cl}_{3} \mathrm{Si}$ & 683 & 13.64 \\
\hline 37.68 & Heptadecane & $\mathrm{C}_{17} \mathrm{H}_{36}$ & 240 & 17.36 \\
\hline 39.44 & 1-Tetradecanol (CAS) & $\mathrm{C}_{14} \mathrm{H}_{30} \mathrm{O}$ & 214 & 5.48 \\
\hline 41.97 & Heptane, 2,2,3,3,5,6,6-heptamethyl & $\mathrm{C}_{14} \mathrm{H}_{30}$ & 198 & 14.71 \\
\hline 43.18 & Eicosane & $\mathrm{C}_{20} \mathrm{H}_{42}$ & 282 & 15.44 \\
\hline 45.31 & Iron, tricarbonyl [N-(phenyl-2-pyridinylmethylene) benzenamine- $\mathrm{N}, \mathrm{N}$ '] & $\mathrm{C}_{21} \mathrm{H}_{14} \mathrm{FeN}_{2} \mathrm{O}_{3}$ & 398 & 10.91 \\
\hline 46.91 & Octadecane & $\mathrm{C}_{18} \mathrm{H}_{38}$ & 254 & 8.93 \\
\hline 47.03 & Pentadecane & $\mathrm{C}_{15} \mathrm{H}_{32}$ & 212 & 10.55 \\
\hline 47.93 & phenylmethyl ester & $\mathrm{C}_{23} \mathrm{H}_{38} \mathrm{O}_{2}$ & 346 & 9.97 \\
\hline
\end{tabular}


Table 7: Mass spectrum and structure of phytocomponents identified by GC-MS analysis

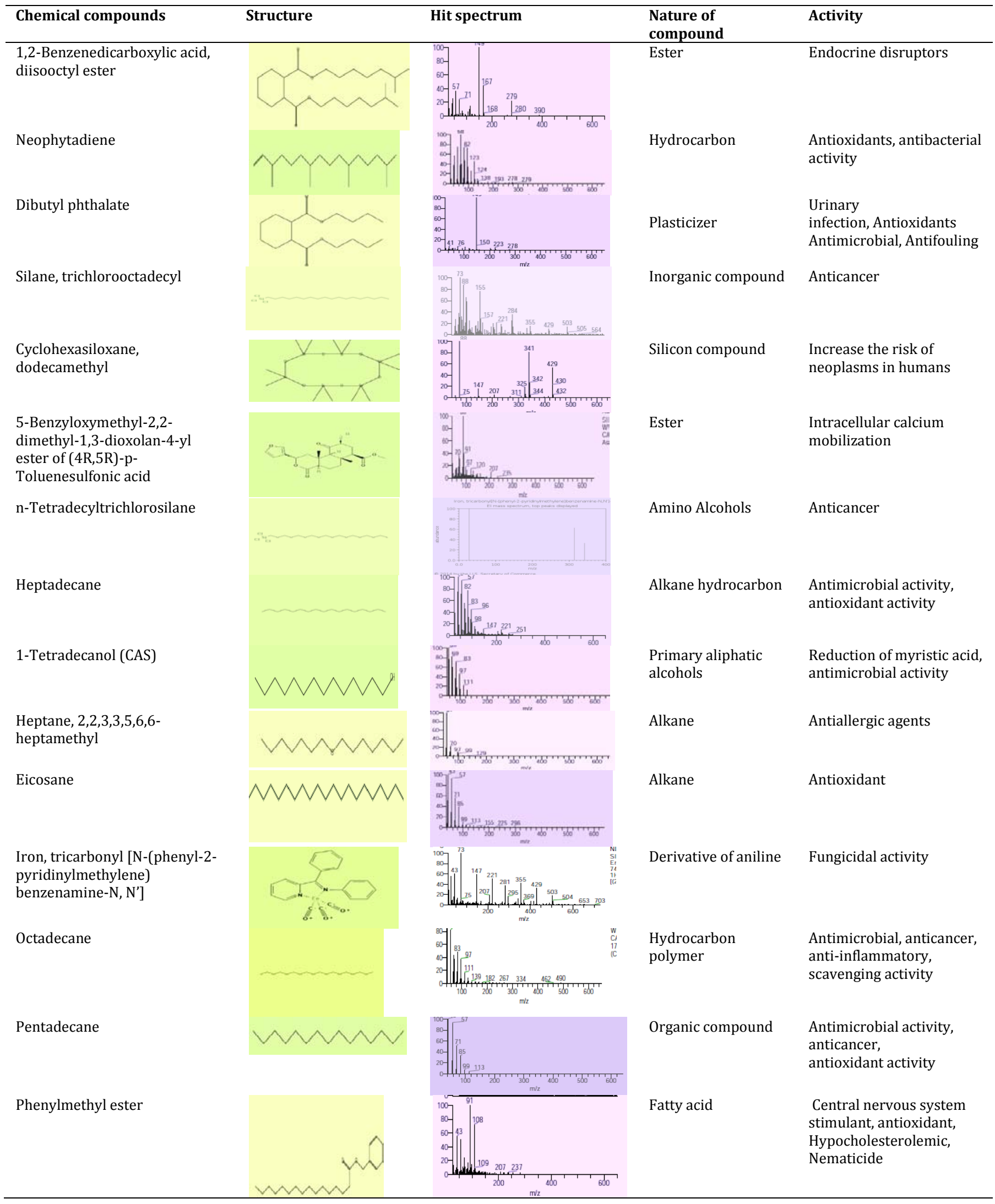

The mass spectra are fingerprint of that compound which can be identified from the data library. The spectra of the compounds were matched with Wiley 9.0 and National Institute of Standards and Technology libraries.
This report is the first of its kind to analyze the chemical constituents of essential oil of C. pedata var. glabra using GC-MS analysis. Similar observations were made by Muhammad Athar Abbasi et al. [31, 32]. 


\section{CONCLUSION}

The pharmacognostic details obtained in the present study will facilitate in providing authentic scientific characterization and identification of $C$. pedata var. glabra used in indigenous medicines. Such parameters also help in establishing pharmacopeial standards which are urgently required not only for the survival of age-old traditional system of medicines but also in view of the fact that these systems are attaining global importance. This simple but reliable standardization will be useful to a layperson in using the drug as a home remedy and also in the pharmaceutical industry for testing the raw material. A pharmacognostical standard serves as a reference piece and helps in the further identification and authentication of this taxon. The presence of various bioactive compounds confirms the application of $C$. pedata var. glabra for various ailments by traditional practitioners. However, isolation of individual phytochemical constituents may proceed to find a novel drug.

\section{CONFLICT OF INTERESTS}

We declare that we have no conflict of interest

\section{REFERENCES}

1. Ambasta SP. The useful plants of India. New Delhi; 1986. p. 112.

2. Singh MP, Himadri Panda. Medicinal herbs with their formulations; 1994. p. 230.

3. Chakraborty MK, Bhattacharjee A. Some common ethnomedicinal uses for various diseases in Purulia district, West Bengal. Indian J Tradi Knowledge 2006;5:554-8.

4. Jain SK, Rao RR. Hand Book of Field and Herbarium Methods. New Delhi; 1970.

5. Fyson PF. The Flora of the Nilgiri and Pulney hilltops. Superintendent, Government Press: Madras; 1915. p. 20-3.

6. Gamble JS, Fischer. CEC, Flora of the Presidency of Madras, Calcutta; 1967. p. 1-3.

7. Matthew KM. The Flora of the Tamil Nadu Carnatic. Rapinet Herbarium St Joseph's College Tiruchirapalli 1983;3:278-9.

8. Johansen DA. Plant Microtechnique. Mc Graw Hill Book Co, Newyork; 1940. p. 523.

9. Wallis TE. Textbook of Pharmacognosy. CBS Publishers and Distributors. $5^{\text {th }}$ ed. New Delhi, India; 1985.

10. Sass JE. Elements of Botanical Microtechnique. McGraw Hill Book Co. Newyork; 1940. p. 222.

11. O'Brien TP, Feder N, Mc Cull ME. Polychromatic staining of plant cell walls by toluidine blue-0. Protoplasma 1964;59:364-73.

12. Esau K. Plant anatomy. John Wiley and sons, Newyork; 1964. p. 767.

13. Tandon HLS. Methods of analysis of soils, plants, water and fertilizers. Fertilizers Development and Consultation Organization. New Delhi, India; 1993. p. 144.

14. Lawrence Evans. DSN Dietary Supplements, Non-Botanicals. Pharmacopeial Forum 2009;28:1545.
15. AOAC. Official methods of analysis of AOAC International. $16^{\text {th }}$ ed. AOAC International, Suite 400, 2200 Wilson Boulevard, Arlington, VA, USA; 1995.

16. WHO. Quality control methods for medicinal plant material. Geneva: WHO; 1992. p. 22-34.

17. Kokate CK, Khandelwal KR, Pawar AP, Gohalz SB. Practical Pharmacognosy, Vallabh Prakashan. $4^{\text {th }}$ ed. New Delhi, India; 1995. p. 107.

18. Massada Y. Analysis of essential oil by gas chromatography and spectrometry, Wiley Pub., New York, London; 1976. p. 69-71.

19. Robert Hook. Micrographic or some physiological description of minute bodies made by magnifying glasses observations inquiries thereupon; 2003. p. 1605-703.

20. Uthayakumari F, Sumathy M. Pharmacognostical studies on the endemic medicinal plant-Jatropha maheswarii Subr and Nayar (Euphorbiaceae). Int J Pharm Tech Res 2011;3;2169-74.

21. Wheeler EA, LaPasha CA. Woods of the Vitaceae-fossil and modern. Rev Palaeobot Palynol 2003;80:175-207.

22. Pragasam A. Pharmacognostic studies on Cissus vitiginea L. International conference on medicinal plants and herbal drugs: Challenges and opportunities in cultivation, sustainable utilization and conservation (ICMPHD); 2010. p. 153-4.

23. Enechi OC, Odonwode I. An assessment of the phytochemical and nutrient composition of the pulverized root of Cissus quadrangularis Bio. Res Gate 2003;1:63-8.

24. Chaudhari MR, Gokhale SB. Biochemistry and clinical pathology. Nirali Prakashan; 1991. p. 72-7.

25. Deb AC. Concepts of Biochemistry. $2^{\text {nd }}$ ed. Book and Allied (P) Ltd., Calcutta; 2004. p. 300-24.

26. Singhal MK. Banana potassium and stroke. J Experi Biol News Scan 2002;40:1322.

27. Dandiya PC, Sharma PK. Biochemistry and clinical pathology (Theory and Practical). Vallabh Prakashan, Delhi; 1996. p. 90104.

28. Ayoka AO, Akomolafe RO, Akinsomisoye OS, Ukponmwan OE. Medicinal and Economic value of Spondias mombin. Afr J Biomed Res 2008;11:129-7.

29. Fumio Watanabe. Vitamin $B_{12}$ sources and bioavailability Minireview, The Society for Experimental Biology and Medicine, School of Agricultural, Biological and Environmental Sciences, Tottori University, Japan; 2007. p. 1266-74.

30. Mertz W. Chromium in Nutrition and Metabolism. Elesvier; 1989. p. $1-14$

31. Muhammad Athar Abbasi, Ali Raza, Tauheeda Riaz, Tayyaba Shahzadi, Aziz-ur-Rehman. Investigation on the volatile constituents of Juglans regia and their in vitro antioxidant potential. Proc Pakistan Acad Sci 2010;47:137-4.

32. Vasantharaj $S$, Senthilkumar $P$, Sathiyavimal $S$, Hemashenpagam N, Vijayaram S. Preliminary phytochemical screening, Antibacterial potential and GC-MS analysis of two medicinal plant extracts, source. Asian J Pharm Clin Res 2013;5(6 Suppl):84. 